\title{
A STUDY OF LOCAL GOVERNMENT STRATEGIES TO PROMOTE YOUTH ENTREPRENEURIAL CLUSTERS IN CULTURAL AND CREATIVE INDUSTRIES
}

\author{
Chi-Sen Hung * \\ No. 129, Sec. 3, Sanmin Rd., North Dist., Taichung City 404336 , Taiwan (R.O.C.) \\ Department of Commercial Design, National Taichung University of Science and \\ Technology, Taiwan, R.O.C \\ Chi-Sen Hung s6317666@gmail.com
}

\begin{abstract}
Taiwan regional revitalization; the Taiwanese government attempted to solve the issues of overpopulation in big cities due to urbanization, whereas the depopulation issues occur in the rural area. In 2015, the Taichung City Government launched the "Reaching-for-Stars Youth, Dream-Come-True in Taichung"(RSY project), which promotes the establishment of youth entrepreneurial clusters in Taichung City and invites young people of cultural and creative industries to return home for entrepreneurship. In order to investigate the Taichung City Government's strategy for promoting this project, this study adopted grounded theory, in-depth interviews, and field surveys. This study proposes the "Entrepreneurship Base Operation Strategy Framework", which contains five operational strategy facets, the government entrepreneurship policy, local entrepreneurship capital and environmental resources, operation management strategy for incubation and counseling, brand management and marketing of the entrepreneurship base, and local sustainable management.
\end{abstract}

Keywords. Cultural and Creative Industry, Youth Entrepreneurship, Design industry

\section{Introduction}

In 2002, the Taiwan government promoted the "Challenge 2008: National Development Plan"; and in the sub-plan "National Major Development project," cultural creative industries was defined as "the accumulation of culture which through the formation and application of intellectual properties, possess potential capacities to create wealth and job opportunities, enhance the citizens' capacity for arts, and elevate the citizens' living environment" [[1], [2]]. This plan assured the development highlights of the cultural creative industries in Taiwan. Cultural creative industries are divided into 15 categories in which the design-related industries are up to nine categories that are separately affiliated to three ministries, which are Ministry of Culture (MOC) the Ministry of Economic Affairs (MOE) and the Ministry of the Interior (MOI). Thanks to the promotion of cultural creative industries, the design industries have grown prosperously in recent years [3].

Taichung city government invited youth of cultural creative industries to return to home for startingup business, launching "Reaching-for-Stars Youth, Dream-Come-True in Taichung"(hereinafter RSY project)[4]. Among them, three places with the status of cultural assets, such as Zhai Xing Cottage, Shenji New Village, and Guangfu New Village, are chosen to provide space for young people to move in and startups, and a maximum of 108 young people can be invited to settle in. Among them, Guangfu 
New Village in the Wufeng District of Taichung City has the largest area and the largest number of units that can be stationed-in there. It is also a demonstrative base for entrepreneurship in a public-run operation mode, and the city government has chosen this base to implement a series of innovative entrepreneurial policies, making it the earliest case of a local government promoting entrepreneurial colonies in Taiwan, and an object for local governments to follow. The purpose of this study is to explore how the Taichung City government promotes youth entrepreneurial clusters in cultural and creative industries as a strategy for regional revitalization goals.

\section{Literature Review}

\subsection{Cultural Parks}

Scholar Syrett [5] had provided the "Local Economic Initiatives," which was a pivotal discourse. He believed that each region could benefit from the distinguished cultural resources by integrating innovative works to revitalize the local economy. The provided way should involve the cooperation of local government, organizations, and the residents to create the value of that region. When it comes to regional economic regeneration, it depends on the implementation of policies of "regional revitalization" while the cultural parks have played an important role in the revitalization of local culture and local industries; and it is as well the successful media of motivating the local economy innovation. Strategical industries cluster may bring competitive advantage to a region [6],[7].

The concept of cultural parks originated in the United States in the 1980s, due to the shifting of the industrial structure, the U.S. government attempt to revitalize the abandoned factories and other idle spaces by implementing strategies of regional revitalization and urban renewal. As for the development of cultural creative industries, it is through the clustering strategy of cultural parks that makes the region into creative clusters [8].

Such a model of preserving, revitalizing, and reusing cultural assets is one of the ways the Taiwanese government promotes cultural and creative industry clusters. From 2003 to 2007, the Ministry of Culture promoted the project of "planning and setting up creative cultural parks," and selected the old wineries in Taipei, Taichung, Chiayi, Hualien, and the Tainan Nanmen warehouses as the five bases for promoting the creative cultural industry project [9]. For the local government, there are the Songshan Cultural and Creative Park and Treasure Hill International Artist Village in Taipei; the Guangfu New Village, the Shenji New Village, and the Qingshui Military Community Culture Park in Taichung; and the Pier-2 Art Center in Kaohsiung...etc. These are all successful cases of adaptive reuse of historical buildings or cultural landscapes with the status of cultural assets.

\subsection{Ideology of Regional Revitalization}

Since the economy market competition has become ever so internationalized, the competitive advantage depends on the region [10]. However, with each country become excessively dependent on the economic activity of big cities, it will cause the shift of population structure from local places to the big cities; and eventually, lead to population decrease and ageing issues to the local places. R.W. Poston wrote about his observation about the State of Montana in his book, the "Small Town Renaissance". He emphasized that the revival of a region should not only depend on the government and city planners' revitalization policies, but also by thinking how the policy would guide residents to automatically devote themselves to the region [11]. The perspective of the discourse was the same as the American non-profit organization, the Project for Public Spaces (PPS), of their opinion on Placemaking [12]. It was emphasized by the PPS that Placemaking is the combination of "place" and "making" that bring multilayer governance connotation through public space planning, design, and operation management ideologies. While after the government putting in various resources for all kinds of constructions, the more important thing is the process of the public promotion process and practices that would make the operation of "Placemaking" independent and sustainable.

Taiwan and Japan have had similar trajectories in terms of land and social development, so there are much to learn from the Japanese government about the policies on regional revitalization. In order to 
prevent the decline of towns and villages, in the early 1990s, the Taiwan Council for Cultural Affairs (CCA) repeatedly invited Japanese scholar Kiyoshi Miyazaki, a professor at Chiba University, to Taiwan to introduce Japan's experience of "building villages" and "building towns", reminding the core of sustainable community management, and prompting Taiwan to initiate the "Comprehensive Community Development" policy, which initially focused on the construction of local cultural performance facilities and cultural activities. From the perspective of how Taiwan promotes the operation of community, the early stage mainly covers human resource cultivation, community forums, commercialize development, and promoting sustainable development [13].

In 2016, the National Development Council promoted the "Designing Flip, Regional Revitalization" plan, expecting the reformation of local images and create featured local industries by introducing the design energy. In 2017, the plan and the corresponded regional revitalization project have been written into an S.O.P. pamphlet. It has been provided as a reference for each county to reform local image through design. With subsidies during 2017 and 2018, there were a total of 18 governments of counties and cities that joined the project of introducing design into local creativity. The plan "Designing Flip, Regional Revitalization" focuses on inventorying the local resources in three basic factors. The "geography factor" includes history, climate, culture, natural resources, and ecology...etc.; and the "industries" factor contains industries of different classes; and the "population variants" factor involves the employed population, regional distribution, religious activities, opinion leader, culture and history workers, and social community. By inventorying the abovementioned basic factors, the resource advantage is confirmed and through the design mechanism of "Innovation, Creativity, Entrepreneurship" (Figure 1) it will create a correlation effect among design, productivity, and marketing. In recent years, the promotion of regional revitalization policy has explicitly shown how Taiwan emphasizes the design industries [14].

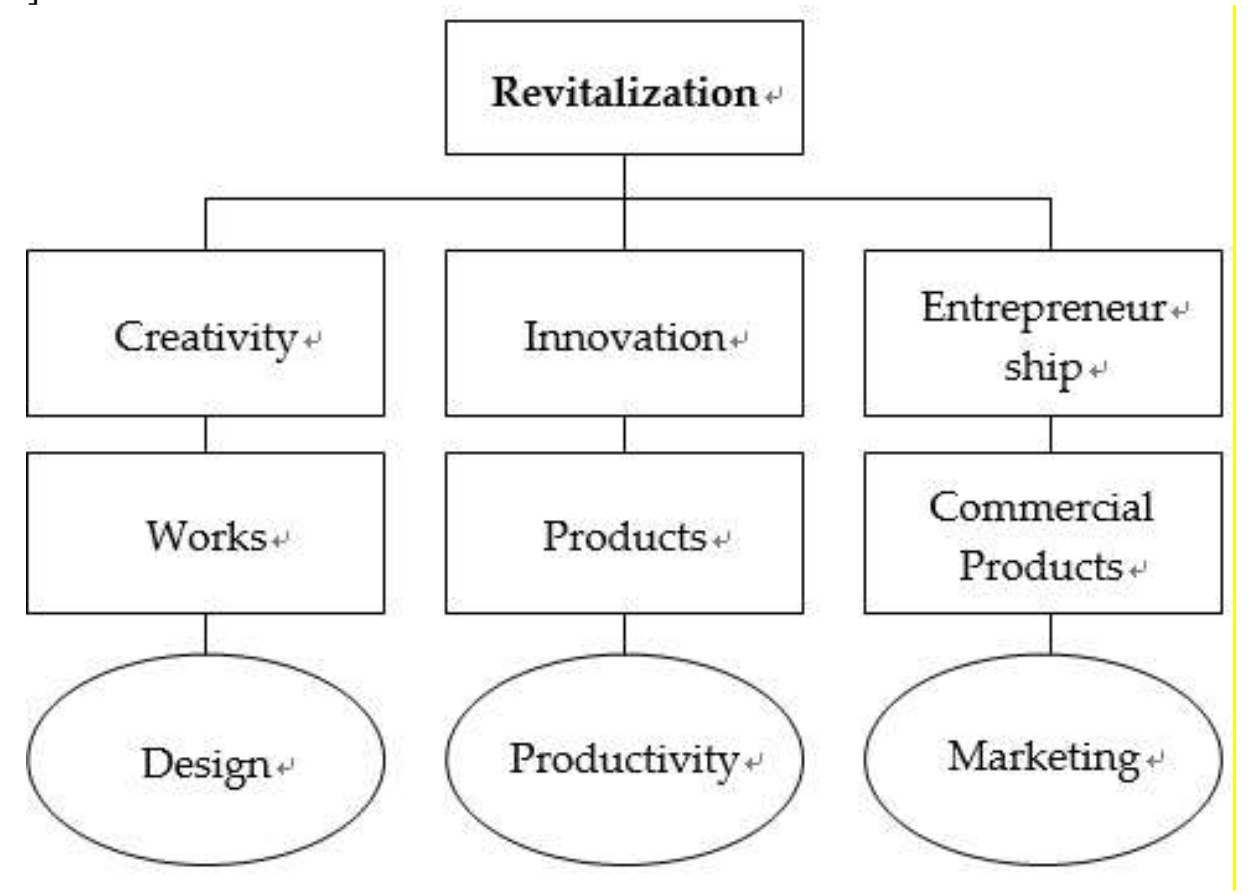

Figure1. Taiwan Regional Revitalization Plan Promotion Concept 
In 2017, the National Development Council(NDC) began a pilot program for local image transformation using the strategies of design-in-place. In that year, 15 counties and cities joined the designing flip program, inviting local design teams to help optimize the image of local industries. From the experience of this pilot project, the NDC has proposed strategies for follow-up, including corporate investment in hometowns, introduction of technology, integration of cross-sector resources, social participation, and brand building, in the hope of achieving the goals of attracting industry to the area, population return, and local prosperity.

Kotler \& Keller [15] believe that market orientation and theory of business will make the regional culture into attractive products or services. From the executive perspective, Kavaratzis \& Ashworth [16] think that the local brand image can be shaped by three procedures, which are 1. the introduction of policies and plans, such as urban planning; 2. Inventorying and vitalizing local resources; 3 . To show local characteristics through multiple forms, such as events, reports, literature, etc.

\subsection{Taichung Entrepreneurship Policies}

About the Taichung City Government promoting the policy of entrepreneurship and incubation policies, it is seen in the September 2020 policy address that the city government has launched 6 measures for youths to return to Taichung for business start-ups. Hereinafter are the six measures [17]:

\subsection{The Taichung City Government Entrepreneurship Incubation Plan:}

In 2015, the city government began the RSY project, inviting Taichung city youths, who have the intention to startup a business, to stationed-in the entrepreneurship base and to provide them with various counseling measures and subsidies. The Taichung City Government once invited over 110 business tutors to attend as the counselor of youth's entrepreneurship, assisting youths with operation management, marketing, advertising, research, applying for a patent, venturing, etc.; and build the INCU Inside (incubation inside) incubation resource matching platform.

\subsubsection{Integrating and Connecting Capital Chain:}

About the funding's for entrepreneurs, the Taichung City Government promoted the research subsidy fund, Start-up youth venture loan, and assisting the Taichung city micro corporation registration.

\subsubsection{Establishing E-Commerce Matching Platform:}

Assisting the verification process of the youth entrepreneur product before officially introducing it to the market, consulting the product adjustment for foreign marketing, and simultaneously hosting the ecommerce promotion events.

\subsubsection{Public Retail Market Inventorying and Business Inviting:}

Inventorying 14 public market stands of Taichung City, providing rent discounts and the youth priority loan.

\subsubsection{Promoting Social Innovation Experimental Base and Star-up Service Single Window:}

Establishing "Social Innovation Experimental Base," inviting the social-entrepreneur based youth business to station in and invite counselor from 5 major fields, business, account, finance, legal affair, and technology, to form the counseling team, and arrange human resource cultivation and information exchange services etc.

\subsubsection{Hosting Youth Entrepreneurship Themed Market:}

Organized by Taichung City Government, combining colleges and universities in Taichung to coorganize themed market that provide youth with a platform to sell the start-up business products.

In addition to the mentioned policy implementations, the Taichung City Government established the "Youth Affairs Advisory Committee (YAAC)" inviting youths to propose advice on city governance. 
Below the Taichung City Government official website, there is a YAAC section for youths to conveniently advise, proposing suggestions, and co-supervising the policies of city government.

\subsection{The RSY project}

The Taichung City Government began promoting entrepreneurial policies in 2012 and firstly focused on assisting the physically and mentally challenged for start-ups by hosting business star-up lessons, venture loan subsidies, and specialist consultation services.

Since 2014, the Taichung City Government has expanded its entrepreneurship policy from supporting physical and mental challenged in the past to assist young entrepreneurs. It has begun planning numerous related services for young entrepreneurs in Taichung City, including entrepreneurship consultation, entrepreneurship diagnosis, lectures, one-on-one mentor counseling in the early stages of entrepreneurship, and interest subsidies for entrepreneurial loans. In the same year, the Wufeng Guangfu New Village was selected as a preparatory base for entrepreneurship incubation. First, the "Guangfu New Station" office was set up to initiate planning the business of entrepreneurial services.

In the August 2014 policy address of the Taichung City Government, the RSY project star-up service platform project was proposed. In 2015, city-designated monuments and cultural landscapes such as the Zhai Xing Cottage (Tanzi District,) Guangfu New Village (Wufeng District,) and Shenji New Village (West District) were selected as the entrepreneurship incubation Base. The funding for the promotion of this project is 55 million NTD.

In 2015, the RSY project was officially launched. In addition to actively repairing and constructing the hardware facilities, transportation construction, and environment of the three entrepreneurship bases, the Taichung City Government put forward more measures for the promotion of entrepreneurship policies, including, expanding the scope of youth loans to include indigenous youths and agricultural youth; the city government cooperates with the Small and Medium Enterprise Credit Guarantee Fund to launch preferential youth entrepreneurship loans; and allocating 38 million NTD. to promote local industrial innovation and research and development promotion plans.

In 2016, the "Zhai Xing Cottage" and the "Shenji New Village" among the three entrepreneurial bases were commissioned by private enterprises under the OT operation mode according to the"Taichung City Government Measures to Promote Private Participation in Public Construction". The "Guangfu New Village" has chosen the public-operated mode from the very beginning. The base has planned a total of 70 stationed space units, which are the largest number of stationed spaces among the three major bases; and therefore, it has also become a demonstration area for the Taichung City Government to promote various entrepreneurial policies.

The Taichung City Government adopts a rolling correction model for the operation of youth entrepreneurship counseling and management. Every month, the current situation of youth entrepreneurship is reported and there are quarterly bureau work meetings, annual youth entrepreneurship operation assessment, and irregular city government inter-bureau meetings to confirm and grasp various difficulties of promoting the plan and propose the solution for it. [4], [17]

\section{Method}

\subsection{Research Design}

This study analyzes the Taichung City Government's strategy to promote youth entrepreneurial clusters in the cultural and creative industries. We chose to collect and analyze data through qualitative research strategies, through systematic data collection rooted in theory, and through the process of induction and interpretation. In-depth interviews with public officials, operation and management units, youth entrepreneurs, local associations, village leaders, residents, etc. 


\subsection{In-depth Interviewees}

The interviewees who participated in this study are as follows:

- Public sector personnel promoting the RSY project: including section chiefs, unit chiefs, and section employees of the Bureau of Labor Affairs, Taichung City Government, a total of 3 people.

- Operation and management unit: There are 3 persons, including 1 operation manager of the Youth Entrepreneurship Base in Guangfu New Village and 2 youth entrepreneurship counselors.

- Young Entrepreneurs: 8 young people were interviewed in the following categories: illustration, visual design, video production, commercial photography, community building, non-profit people's groups, craft creation, and cultural experience teaching.

- Local people: 1 secretary general and 1 mayor of a local non-profit organization, and 7 residents, for a total of 9 people.

\subsection{Implementation Steps of Grounded Theory}

The total number of interviewees in this study was 23, and the interview period was from November 2020 to April 2021. Each interview lasted about one to two hours and was recorded by audio recording. Two university teachers in the field of business management, one in the field of innovation and entrepreneurship counseling, and two in the field of brand marketing were invited to conduct data analysis.

The procedure for conducting the grounded theory in this study is as follows:

3.3.1. Open Coding: First, the data collected in this study are compared, summarized, and categorized, and the related concepts are categorized into the same category, and at the same time, the categories are divided into primary and secondary categories according to their interrelationships, and the categories are named.

\subsubsection{Axial Coding: To explore the interrelationship between major and minor categories. An} attempt is made to establish a sub-theoretical framework from which relationships between cause and effect or related categories can be established.

3.3.3. Selective Coding: Based on the framework of the previous axial coding, we explore the core category and unify all the categories into a complete theoretical framework. At this stage, this study proposes a preliminary draft of the "Entrepreneurship Base Operation Strategy Framework and Key Factors".

3.3.4. In order to ensure the accuracy of the theoretical framework developed by this study based on the grounded theory, this study submitted the draft of "Entrepreneurship Base Operation Strategy Framework and Key Factors" to four interviewees, including a member of the Labor Bureau of the Taichung Municipal Government, a facilitator of the Youth Entrepreneurship Service Platform Project, a consultant, and a young entrepreneur, to confirm the strategic framework and key factors once again and provide suggestions. Finally, the researcher revised the "Entrepreneurship Base Operation Strategy Framework and Key Factors" based on the suggestions.

\section{Data Analysis and Discoveries: Entrepreneurship Base Operation Strategy Framework and Key Factors}

This study analyzes with the grounded theory and through the three-stage analysis process and the revalidation process, we proposed the five major components of the entrepreneurial base operation strategy and the key factors. In this study, we present the "Entrepreneurship Base Operation Strategy Framework and Key Factors" as shown in Figure 2. 
The five major facets can be further divided into three aspects, the top level being the "policy and environment aspect", which includes "government policies on entrepreneurship" and "local environmental resources for entrepreneurship". These two structures have a mutual influence on each other. The central government and local governments can formulate relevant policies and implementation plans based on the near, medium and long-term goals promoted by the state, cities and localities, so as to shape social entrepreneurial resources and atmosphere and inject local entrepreneurial resources into the environment. The local environment can provide resources for entrepreneurs by preserving the tangible and intangible cultural assets, as well as the humanities, industries, nature, and environment that have been accumulated over a long period of time.

The middle level is the "Operation Management and Brand Marketing Aspect", which includes the "Operation Management Strategy of Incubation Counseling" and the "Brand Management and Marketing of the Entrepreneurial Base", which mainly defines the internal operation mechanism and important development ideas and strategies of the entrepreneurial base.

The third level describes the long-term goal of local entrepreneurship, which is "the return of young people to local entrepreneurship \& the sustainable management" of local communities.

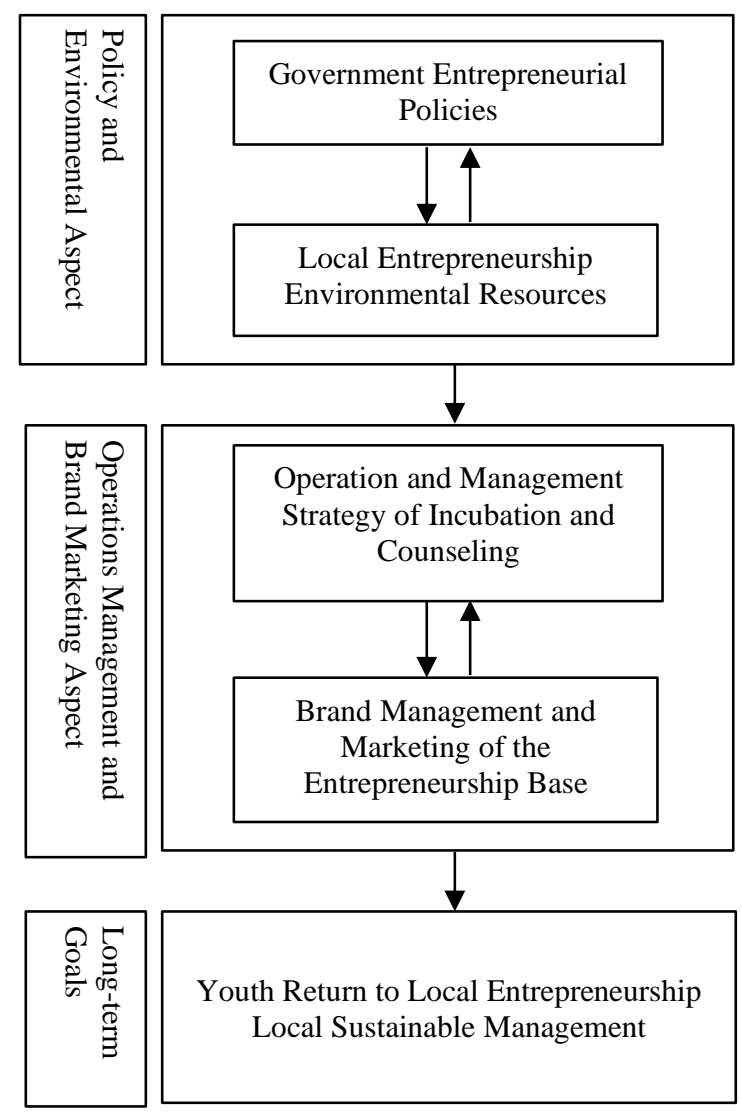

Figure2. Entrepreneurship Base Operation Strategy Framework and Key Factors

There are several key elements in the above five different facets, and the details are as follows:

Facet 1: Government Entrepreneurial Policies

Definition: Entrepreneurship policies and promotion formulated by the central and local governments, Shaping the national entrepreneurial atmosphere and friendly environment.

\section{Key Factors:}

- Basic Environment Construction: The entrepreneurial environment just as any economic activity, must be built on a robust infrastructure, such as transportation systems, public facilities, 
hardware, networks, and education. Especially in remote areas, infrastructure is the key factor to local development.

- The Central Government Entrepreneurship Policy: The national entrepreneurship policy is jointly implemented by various ministries and sectors. In Taiwan, the Ministry of Economic Affairs, the Ministry of Labor, the Ministry of Education, and the Ministry of Culture, etc. focus on the topic of youth entrepreneurship, promoting entrepreneurship policies in different fields and perspectives, and shaping the overall entrepreneurial conditions of the country in their respective roles.

- Local Government Entrepreneurship Policies: The local government thoroughly analyzes the local entrepreneurship needs, resources and trends, proposing local entrepreneurship policies and plans, and provide citizens with entrepreneurship counseling, incentives and subsidies, research and development resources, funds and loans, space and equipment. When the RSY project was implemented in the early part of 2015, it chose to invite entrepreneurial youth to enter the entrepreneurial base with the strategy of providing monthly subsidy incentives and lower rental fees, which are lower than the neighboring rent market. After interviewing with the stationed-in youth in this study, it is learned that although the overly preferential entrepreneurial subsidy strategy may attract entrepreneurial youth to be competitive to enter the base or achieve the promotion of the entrepreneurial plan in the early stages; however, relatively speaking, the stable incentive incomes have led to the indolence of the young entrepreneurial operation and gradually losing the motivation and dynamics of operation. In order to adjust the operating model and promote the operating dynamics of youth entrepreneurship, since 2017, the Taichung City Government has abolished the monthly entrepreneurship subsidies and changed into "entrepreneurship incentives" to provide youth entrepreneurs encouragement and strategically driving their positive attitude and operating dynamics.

Facet 2: Local Entrepreneurship Environmental Resources

Definition: The preparatory resources of the external environment outside the entrepreneurial base, as well as the internal environmental resources shaped by the incubation unit within the entrepreneurship base.

\section{Key Factors:}

- Public Constructions and Facilities: For the implementation of regional development, local governments formulate short-term, medium-term and long-term policy goals and plan to build places based on the aspects of nature, population, culture, industry, education and other aspects, in order to enhance the local living, employment and entrepreneurial environment.

- Cultural Heritages: The accumulated cultural contexts in the course of regional development can become an important factor in the development of cultural and creative industries. It includes tangible cultural heritages such as monuments, colonies, ruins, cultural landscapes, antiquities, etc.; as well as intangible cultural heritages such as performing arts, crafts and techniques, folk activities, etc. In addition, the common memory of the local development process is also an important asset of the place. The Wufeng District, where Guangfu New Village is located, is an important area in Taiwan's modern development history, with rich cultural connotations, including industrial development, local construction, culture and education, environment and ecology, etc. More importantly, Guangfu New Village is rich in the humanistic spirit of "innovative experimentation" and "democratic movement" in Taiwan's modern history, which coincides with the entrepreneurial spirit. It has also become an important spiritual asset in the brand story of youth entrepreneurship.

- Natural Environmental Conditions: Natural environmental resources directly affect the living culture and memory of residents, forming local exclusive industries, economy, education and research patterns. The Richter scale 7.3 earthquake that struck central Taiwan on September 21, 1999, killing 2,415 people in Taiwan, has been an unforgettable tragic memory for the people 
of Taiwan. Major historical events and environmental catastrophes left wounds to the local area, which become national and international memories.

- Local Research and Development Resources: the establishment of local universities has brought changes in lifestyle and demographic structure to local life. There is Chaoyang University of Technology at the north end of Wufeng and The Asia University at the south end of Wufeng. Due to the dense population around the university, small business districts and accommodation areas have been naturally formed. Chaoyang University of Science and Technology has an affiliated kindergarten, while Asia University is affiliated with an art museum, a hospital, to enhance the quality of life of residents. In addition, the two universities have respectively set up innovation incubation centers and entrepreneurship accelerators, to integrate on-campus academic, research, incubation, research, and development energies, forming support for local entrepreneurship research and development, while providing important resources such as technology, equipment, manpower, space and so on for the need of young people when they return to the local place to start a business.

Facet 3: Operation and Management Strategy of Incubation and Counseling

Definition: The operation and management unit of the entrepreneurship base must promote the operating dynamics of entrepreneurial youth through management strategies, and bear the responsibility of park maintenance and operation management

\section{Key Factors:}

- Induced Management Strategy: With a large number of entrepreneurs clustered in the entrepreneurial base, the operating unit should think about the co-opetition relationships that arise after the agglomeration of entrepreneurs. By managing and guiding moderate competition and cooperation, it will promote the rapid growth of entrepreneurs' operational effectiveness, product and service quality. With the entrepreneurship base becoming a platform for entrepreneurial exchange, the youth here are not only concerned with their own entrepreneurial work, but have elevated themselves to thinking about mutual cooperation, resource sharing, and the mutually beneficial relationship gained through joint research and development (Figure 3). In the entrepreneurial base, young people can freely share their production capacity through exchanges and cooperation.

- Public-Private Cooperation with Mutual Trust: The characteristics of the study case are that the cultural landscape has been chosen as the entrepreneurship base and it is based on the model of "government owned and managed" framework. The government owned and managed model makes the direction of operation somewhat contains policy declarations and demonstrations. In addition, since the public sector has its restrictions in terms of implementation, the relationship of mutual trust between public and private cooperation has become a critical key factor. The private sector, as the executive unit, regularly gives feedbacks to the operation status of youth, while the city government, based on various difficulties, initiates cross-bureau integration meetings from time to time, proposing countermeasures, and corrects the operation strategy on a rolling basis. 


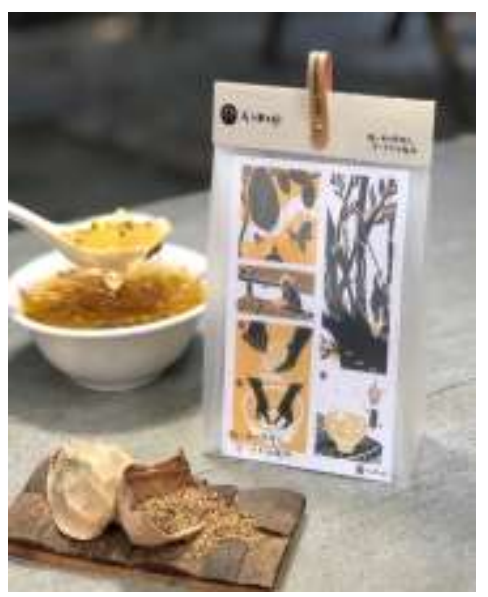

Figure 3. The picture shows the results of cooperation between young people engaged in the management of agricultural products and young people engaged in visual design.

- Planning Counseling Stages According to The Entrepreneurship Development Phases: To provide appropriate incubation counseling, the operation team should provide different types of incubation and promotion counseling according to the development history of individual entrepreneurial units; and according to the characteristics of incubation needs, organize a database of entrepreneurial consultants. From the results of the study, it can be seen that after the young people have moved into the entrepreneurship base, the city government will divide them into four incubation and counseling stages according to the period of stay, namely the incubation period, the experimental period, the promotion period and the feedback period. At each stage, different counseling focuses and actual counseling actions are planned, and the focus and actual actions of each stage are summarized in Table 1.

- Promote the Operational Dynamics: In the case of Guangfu New Village, it has been abandoned for a long time due to the relocation of the population of the family village and the impact of the earthquake. When choosing this place as a business base, the consumption behavior in this region must be reconstructed. When implementing incubation counseling, the operating unit divides the counseling cycle into four stages. Among them, in order to mentor entrepreneurial youth who belong to the "Experimental Period," the operating unit will implement the brand impression building plan of Guangfu New Village, hosting different types of activities, cooperating with private enterprises, travel agencies, schools and other units, and attract different types of people, group, consumers, and visitors to visit, have fun, and learn in Guangfu New Village.The data collected in this study showed that in 2017, the number of group visitors by appointment grew to about 900 people; in 2018, the number of group visitors by appointment grew to 4,300 people; in 2019 , the number of group visitors by appointment grew to 9,500 people; but in 2020, the number of group visitors by appointment fell to about 4,000 due to the spread of COVID-19 pandemic. This study observes that the three-year observation of the growth of the number of booked groups from 2017 to 2019 has indeed significantly contributed to the growth of visitor flow, and the growth of visitor flow has led to the entry of diversified consumer demand into the venture base, which is as expected by the operating unit. This is the biggest difference in the operation mechanism and counseling strategy between the open space chosen by the city government as the incubation base and the general office type incubation base. 
Table 1. Incubation Counseling Periods and Highlights

\begin{tabular}{|c|c|c|}
\hline Period & Counseling Highlights & Actual Behavior \\
\hline $\begin{array}{l}\text { Incubation } \\
\text { Period } \\
\text { (0-1 year after } \\
\text { stationed-in) }\end{array}$ & $\begin{array}{l}\text { - Cultural heritage preservation } \\
\text { and maintenance counseling } \\
\text { - Entrepreneurial professional } \\
\text { skills improvements } \\
\text { - Entrepreneurial cognition and } \\
\text { attitude improvements }\end{array}$ & $\begin{array}{l}\text { - Cultural heritage preservation and maintenance } \\
\text { plan counseling } \\
\text { - Hosting entrepreneurial business start-up } \\
\text { lessons } \\
\text { - Youth product development consultation } \\
\text { - Arranging internships for university students, } \\
\text { introducing human resources } \\
\text { - one-on one counseling matching. bring about co- } \\
\text { working results }\end{array}$ \\
\hline $\begin{array}{l}\text { The } \\
\text { Experimental } \\
\text { Period } \\
\text { (1-2 year after } \\
\text { stationed-in) }\end{array}$ & $\begin{array}{l}\text { - Market group experimentation } \\
\text { - Various resource chaining } \\
\text { - Mutual growth among youth } \\
\text { entrepreneurs } \\
\text { - Constructing public relations }\end{array}$ & $\begin{array}{l}\text { - Introducing various consumer groups to the } \\
\text { entrepreneurship base } \\
\text { - Stimulating the co-opetition relationship } \\
\text { between youths } \\
\text { - By hosting entrepreneurship base activities, } \\
\text { attracting media's attention } \\
\text { - Matching upper-stream and lower-stream } \\
\text { resource with the assist of consultants. } \\
\text { - Matching Wufeng District's local resources } \\
\text { - Through Experimenting and adjusting to } \\
\text { eventually establish the operating pattern }\end{array}$ \\
\hline $\begin{array}{c}\text { The } \\
\text { Promotion } \\
\text { Period } \\
\text { (3-4 years } \\
\text { after } \\
\text { stationed-in) }\end{array}$ & $\begin{array}{l}\text { - Market channel expansion } \\
\text { - Integrated marketing } \\
\text { - Self-owned brand } \\
\text { establishment } \\
\text { - Fund Matching }\end{array}$ & $\begin{array}{l}\text { - Counseling the operation of self-media and } \\
\text { social media } \\
\text { - Digitalization Counseling } \\
\text { - Business brand image, design and operation } \\
\text { - Hosting fund-raising, financing, angel-capital } \\
\text { matchmaking meetings }\end{array}$ \\
\hline $\begin{array}{l}\text { The } \\
\text { Feedback } \\
\text { Period } \\
\text { (half year } \\
\text { before } \\
\text { leaving and } 1 \\
\text { year after } \\
\text { departure) }\end{array}$ & $\begin{array}{l}\text { - Graduation Counseling } \\
\text { - Transferring to other places for } \\
\text { entrepreneurship } \\
\text { - Feedback sharing }\end{array}$ & $\begin{array}{l}\text { - Assist the graduated youth entrepreneurs for } \\
\text { departure } \\
\text { - Tutoring graduated youth to continue to take } \\
\text { root in local entrepreneurship } \\
\text { - Graduated youth entrepreneurs feedback, } \\
\text { sharing resources and hosting resource } \\
\text { matchmaking } \\
\text { - Inviting graduated youth to join the consultant } \\
\text { group and serve as a mentor } \\
\text { - Establishing the Taichung City Government } \\
\text { Youth Affairs Advisory Committee (YAAC) }\end{array}$ \\
\hline
\end{tabular}


Facet 4: Brand Management and Marketing of the Entrepreneurship Base

Definition : When choosing an open cultural park as the Entrepreneurship base, the overall brand impression and operation and marketing must be considered

\section{Key Factors:}

- Operational Positioning: By Using an open cultural park as a entrepreneurship base, although it starts with youth entrepreneurship education, it is still necessary to consider the brand positioning and services for different consumer groups at the same time. In the case of this study, the consumer groups served by the Guangfu New Village Entrepreneurship Base include: young entrepreneurs, neighborhood residents, local schools, education and learning groups, group tourists, and general tourists. While in the hearts of different groups, there are different brand impressions of Guangfu New Village. The responsibility for its brand management needs to be carried by the operation and management unit at the same time.

- Creating demand: Using an open cultural park as an entrepreneurship base, it is closely linked to local industry, economy, education and life. Local needs can be re-shaped or created through operational strategies. The more diverse needs are generated, the more effective the operational dynamic will be. Take the case of this study as an example, the needs created by Guangfu New Village include: the consumption needs of tourism, experiential education and learning needs, industrial technology cooperation and local economic activation needs. Contrastingly, entrepreneurs also have different needs and dependencies on the place such as, upstream and downstream resource supply needs, commodity and service research and development needs, technology and capital cooperation needs, and family life needs.

- Media Management: The media is the external communication channel, and brand management needs to provide the media as the material for publicity through the accumulation of many activities and events. Besides traditional print, advertising, and broadcast media, under the attention and promotion of the Taiwan government's mobile communications construction, the communication efficiency has fully reached $5 \mathrm{G}$. This drives entrepreneurs to flexibly use mobile communications, self-media management, and mobile payment technologies. Finally, brand management and marketing is the task for each related person. From the Taichung City Government, the Labor Affairs Bureau, the management unit, to every stationed-in youth. All should work together to build the brand impression of Guangfu New Village in the hearts of consumers.

- External Channel Expansion: Not only allowing youths to come in and be stationed-in the base, but also bring these youths out! The management unit should manage the common brand of Guangfu New Village Youth Entrepreneurship Base, assisting in the expansion of various types of channels, including domestic and foreign, offline, and online, and lead entrepreneurs to face different market characteristics. On the one hand, it helps to find and confirm the target market, and on the other hand, it also acclaims the brand impression of Guangfu New Village Entrepreneurship Base to the world.

Facet 5: Youth Return to Local Entrepreneurship \& Local Sustainable Management

Definition: Local entrepreneurial base, highly interactive with the region in which it is located, works together towards the vision of local sustainable development by enhancing local attachment

\section{Key Factors:}

- Cultural Creative Industries Cluster: The operation of an Entrepreneurship Base, specifically the commercial activities, must have the vertical up-stream and down-stream cooperative relationship as well as horizontal relationship of operation and cooperative alliance. Taichung City government promoted the development of start-up business policies, choosing cultural creative industries as the major business model. This created industries clusters, as the energy of cultural creative and design channeling through local regions, it brings about commercial activities, providing neighborly residents with participation and connection opportunities, 
offering diversify design services and industrial stimuli, while gradually improving the acknowledgement and the cohesiveness towards the entrepreneurship base.

- Preservation, Revitalization, and Reuse of The Cultural Heritages: Cultural parks with historical buildings and cultural landscape areas as entrepreneurial bases not only provide youth entrepreneurs with affordable rental space in the early stages of entrepreneurship, but also provide citizens with tangible cultural heritage as the "quasi-museums," which attracts people to visit, guided tours and learning, and achieve the function of cultural promotion and education as well as cultural heritage maintenance.

- Entrepreneurial Atmosphere: Since 2014, the Taichung City Government has promoted the policy vision of "making Taichung City the most suitable place for entrepreneurship in Taiwan". The plans implemented include the establishment of entrepreneurial bases, incentives, subsidies, counseling services, entrepreneurial service platforms, capital matching, loan concessions, entrepreneurial competitions, and entrepreneurial achievements exhibitions and sales meetings. The"Youth Affairs Unit" established in 2019 initiated cooperation with 17 Taichung City University incubation centres, hosting on-campus entrepreneurial activities, set up clubs, hosting lectures and courses, and give entrepreneurial incentives, etc., to enhance the overall entrepreneurial atmosphere in Taichung City from the bottom up.

- Links to Local Life: As youth entrepreneurs are brought to the local place, young people do not only start a business but also start a family and live in that place. Therefore, in addition to the resources needed to start a business, local governments should enhance local infrastructure construction to improve the quality of life. The strategy of promoting regional developments of Taichung City Government includes infrastructure projects such as transportation construction, child care services, educational resources, medical systems, local hydraulic management, and ecological rehabilitation so that local living functions can be improved and the return of the population to the place can be sustainable.

\section{Conclusion}

During the study, we found that the Taichung City Government has skillfully channeled the energy of cultural and creative industries into the local community, making design talents and young people return to the local community to start their own businesses. In the process of youth entrepreneurship and design creation, we also sorted out the thinking of local cultural contexts, showing the important role and charm of design in the process of shaping local brands.

The results of the study propose a strategic framework for the operation of the entrepreneurship base, with five major facets and key factors included in the facet. During the operation period, the study also found that such an operation model is gradually formed through continuous cooperation between the public and private sectors and continuous rolling revisions, showing the results of collaborative governance between the public and private sectors. Let an abandoned family home be regenerated through the power of policy, community, academia and industry, and work towards sustainable development.

Such a process not only revitalizes the entrepreneurial base itself, but also changes the lifestyle of local people, revitalizes cultural heritages to enhance the local tourism economy, and even drives the cooperation, linkage and development of local industries.

\section{References}

[1] Development of the Cultural and Creative Industries Act. Ministry of Culture (Taiwan): https://law.moj.gov.tw/ (accessed on 20 July 2021)

[2] Executive Yuan, Republic of China (Taiwan). Available online: https://english.ey.gov.tw/ (accessed on 15 July 2021)

[3] Ministry of Culture, Republic of China (Taiwan): http://english.moc.gov.tw/ (Accessed 17 July 2021)

[4] Labor Affairs Bureau of Taichung City Government (Taiwan). Available 
online:https://www.labor.taichung.gov.tw/ (accessed on 23 July 2021)

[5] Syrett, S. Local Development: Restructuring, Locality, and Economic Initiative in Portugal. Brookfield, Vt., USA: Avebury, 1995.

[6] Santagata, W. Cultural Districts, Property Rights and Sustainable Economic Growth. International Journal of Urban and Regional Research, 26(1), 9-23, 2002

[7] Mateos-Garcia, J., Bakhshi, H. The geography of creativity in the UK. London: Nesta, 2016.

[8] Siepel, J., Camerani, R., Masucci, M., Ospina, J. V., Casadei, P., Bloom, M. Creative Industries Radar Mapping the UK's Creative Clusters and Microclusters, London: Creative Industries Policy \& Evidence Centre led by Nesta, 2020.

[9] Bureau of cultural Heritage, Ministry of Culture: https://www.boch.gov.tw/en/ (Accessed 17 Jun 2021)

[10] Porter, M., Clusters and the New Economics of Competition, Harvard Business Review, 76(6), 77-90, 1998.

[11] Poston, R. W. Small Town Renaissance: A Story of the Montana Study. New York: Harper \& Brothers, 1950.

[12] Project for Public Spaces (PPS). Available online: http://www.pps.org/ (accessed on 23 July 2021)

[13] Capraro, J. F. Community Organizing + Community Development $=$ Community Transformation . Journal of Urban Affairs, 26(2), 151 - 161, 2004.

[14] National Development Council (Taiwan). Available online: https://www.ndc.gov.tw/ (accessed on 20 July 2021)

[15] Kotler, P., Keller, K. L. Marketing management. New Jersey: Pearson Education, 2009.

[16] Kavaratzis, M. \& Ashworth, G. J. City branding: An effective assertion of identity or a transitory marketing trick? Place Branding and Public Diplomacy, 3(2), 183-194, 2005.

[17] Taichung City Governmen (Taiwan). Available online: http://www.taichung.gov.tw/ (accessed on 8 July 2021) 